\title{
A novel proteasome inhibitor acting in mitochondrial dysfunction, ER stress and ROS production
}

\author{
Durvanei Augusto Maria - Jean Gabriel de Souza - Katia L. P. Morais • \\ Carolina Maria Berra • Hamilton de Campos Zampolli • Marilene Demasi • \\ Simone Michaela Simons • Renata de Freitas Saito • Roger Chammas • \\ Ana Marisa Chudzinski-Tavassi
}

Received: 8 August 2012 / Accepted: 16 August 2012 / Published online: 14 September 2012

(C) The Author(s) 2012. This article is published with open access at Springerlink.com

Summary In cancer-treatment, potentially therapeutic drugs trigger their effects through apoptotic mechanisms. Generally, cell response is manifested by Bcl-2 family protein regulation, the impairment of mitochondrial functions, and ROS production. Notwithstanding, several drugs operate through proteasome inhibition, which, by inducing the accumulation and aggregation of misfolded or unfolded proteins, can lead to endoplasmic reticulum (ER) stress. Accordingly, it was shown that Amblyomin-X, a Kunitztype inhibitor identified in the transcriptome of the Amblyomma cajennense tick by ESTs sequence analysis of a cDNA library, obtained in recombinant protein form, induces apoptosis in murine renal adenocarcinoma (RENCA) cells by: inducing imbalance between pro- and

Durvanei Augusto Maria, Jean Gabriel de Souza and Katia L. P. Morais equally contributed to this work

D. A. Maria · J. G. de Souza K. L. P. Morais · C. M. Berra

H. d. C. Zampolli $\cdot$ M. Demasi $\cdot$ S. M. Simons •

A. M. Chudzinski-Tavassi $(\square)$

Laboratório de Bioquímica e Biofísica- Instituto Butantan,

Av. Vital Brazil, 1500-CEP,

05503-900 São Paulo, SP, Brazil

e-mail: amchudzinski@butantan.gov.br

J. G. de Souza • K. L. P. Morais • A. M. Chudzinski-Tavassi

Departamento de Bioquímica, Universidade Federal de São Paulo,

São Paulo, SP, Brazil

H. d. C. Zampolli • A. M. Chudzinski-Tavassi

Programa de Pós-Graduação Interunidades em Biotecnologia,

USP, IPT, Instituto Butantan,

São Paulo, SP, Brazil

R. de Freitas Saito $\cdot$ R. Chammas

Faculdade de Medicina da USP, LIM24-Laboratório de Oncologia

Experimental, Universidade de São Paulo,

São Paulo, SP, Brazil anti-apoptotic Bcl-2 family proteins, dysfunction/mitochondrial damage, production of reactive oxygen species (ROS), caspase cascade activation, and proteasome inhibition, all ER-stress inductive. Moreover, there was no manifest action on normal mouse-fibroblast cells (NHI3T3), suggesting an Amblyomin-X tumor-cell selectivity. Taken together, these evidences indicate that Amblyomin-X could be a promising candidate for cancer therapy.

Keywords Apoptosis $\cdot$ Bcl-2 family protein - Caspase · Reactive oxygen species $\cdot$ Proteasome $\cdot$ Endoplasmic reticulum stress $\cdot$ Amblyomin-X

\begin{tabular}{ll}
\multicolumn{2}{l}{ Abbreviations } \\
ROS & reactive oxygen species \\
RNS & reactive nitrogen species \\
NO & nitric oxide \\
ER & endoplasmatic reticulum \\
eIF2 $\alpha$ & alpha subunit of translation initiation factor \\
GRP78 & 78kDa glucose-regulated protein \\
GADD153 & nuclear transcription factors of growth \\
& arrest and DNA damage \\
RENCA & murine renal adenocarcinoma \\
SEM & scanning electron microscopy \\
$\mathrm{UPR}^{2+}$ & unfolded protein response \\
{$\left[\mathrm{Ca}^{2+}\right]_{i}$} & intracellular calcium concentration
\end{tabular}

Introduction

Apoptosis induction has been the subject of many studies, not only of therapeutic potential, but also for a better understanding of the cell mechanisms involved in various forms of biological response, such as aging [1-3]. The process 
itself comprises a highly conserved mechanism, which can be induced by a variety of physiological or pathological conditions, in which caspases and mitochondria play a crucial role [4]. Except for death-domain receptors, the molecular mechanisms by which the many different pro-apoptotic stimuli, such as irradiation, chemotherapeutics or growth factor depletion, signal and initiate mitochondrial changes, are currently not well understood. There is agreement that cytochrome c action has two important consequences: (a) caspase cascade activation by the interaction of cytochrome c with Apaf-1 and procaspase-9; and (b) inhibition of the mitochondrial electron transfer chain, thereby resulting in the reduction of oxidative phosphorylation, inducement of reactive oxygen species (ROS) production, and finally, impairment of cellular ATP production during secondary necrosis [5].

Although mitochondria are the major source of ROS, these can also be derived from several intracellular sources, including $\mathrm{NAD}(\mathrm{P}) \mathrm{H}$ oxidase, xanthine oxidase, uncoupled nitric oxide synthase and ER stress [6-8]. Apoptosis is also regulated by various ROS and nitrogen species (RNS) [8-10]. ROS, such as hydrogen peroxide $\left(\mathrm{H}_{2} \mathrm{O}_{2}\right)$, superoxide radicals $\left(\mathrm{O}_{2}{ }^{\circ}\right)$ and hydroxyl radicals $\left({ }^{\circ} \mathrm{OH}\right)$, by-products of normal oxygen metabolism, participate in normal cell functions, and act as intracellular signaling molecules in a series of biological processes [9-11]. Nevertheless, imbalance in ROS production may have a cytotoxic effect. Furthermore, subtle changes in the RNS production rate, as nitric oxide (NO), may critically impact cell homeostasis, thereby initiating a series of cellular signaling processes, including apoptosis $[9,12]$.

Bcl-2 and p53 proteins are among those involved in mitochondrial dysfunction and damage, as well as ROS production $[13,14]$. The Bcl-2 proteins are located within the outer mitochondrial membrane, the nuclear envelope and the endoplasmic reticulum (ER) of cells. Whereas anti-apoptotic proteins stabilize the mitochondrial membrane, pro-apoptotic proteins induce the release of cytochrome c, thereby activating effector caspases, such as caspase-3 [15-17]. p53 proteins, known as the "guardians of the genome", play an important role in maintaining DNA integrity and apoptosis induction, by selectively removing damaged cells and protecting the organism against cancer development [18-20]. It is well known that p53 are involved in the regulation of the transcriptional levels of pro- and anti-apoptotic genes, death receptors, and those other factors involved in the different steps of the apoptotic pathway [14]. For example, this protein can directly activate Bax [21], or directly bind to $\mathrm{Bcl}-\mathrm{XL}$ [22] and Bcl-2 proteins, in order to induce mitochondrial permeabilization, and thus release cytochrome c.

Certain chemotherapeutic drugs have been specifically designed to induce apoptosis through mitochondrial dysfunction and damage, and ROS production, thus activating cytotoxic action. Nonetheless, some of these, most notably proteasome inhibitors, induce cell death through the ER-stress mediated apoptotic pathway [23-25]. ER organelle is involved in the synthesis, structural modification and transport of proteins and lipids [26]. When newly synthesized proteins in ER do not present a correct folding, they are retro-translocated to the cytosol, where they are immediately directed to proteassomal degradation $[27,28]$. This mechanism plays an important role in reducing the amount of misfolded or unfolded proteins in ER. The blockage of proteasome proteolytic activity by pharmacological inhibitors, such as bortezomib/PS-341, severely compromises the removal of proteins with impaired conformational structure, thereby leading to their subsequent accumulation inside the ER lumen, with the consequential overloading $[29,30]$. When these acute or chronic structural and functional disturbances reach the point of compromising ER integrity, there is a specific stress response, which, by various mechanisms, activates anti-apoptotic, apoptotic cell, or block cell cycle progression [31]. Amongst others, ER stress involves (a) specific transcriptional and translational responses, such as, phosphorylation of the alpha subunit of the translation initiation factor eIF (eIF2 $\alpha$ ), (b) the activation of chaperone $78 \mathrm{kDa}$ glucose-regulated protein (GRP78), as well as nuclear transcription factors of growth arrest and DNA damage (GADD153), (c) ER-specific caspase-12, and (d) calcium imbalance [32, 33].

Within this context, Amblyomin-X was recently shown to be a proteasomal inhibitor, selectively proapoptotic activity in tumor human cells (SK-Mel-28 and Mia-Paca-2) [34]. This molecule, obtained in recombinant protein form, is a Kunitz-type inhibitor (GenBank accession AAT68575) identified in the transcriptome of the Amblyomma cajennense tick by ESTs sequence analysis of a cDNA library [35]. Simultaneous studies of Murine Renal Adenocarcinoma cells (RENCA) have shown that Amblyomin- $X$ is also capable of inducing apoptosis in this lineage [36]. In this report, it was demonstrated that the pro-apoptotic mechanisms used by Amblyomin-X to trigger effects in RENCA cells, include pro- and anti-apoptotic $\mathrm{Bcl}$ family protein activation, dysfunction/mitochondrial damage, ROS production, caspase-cascade activation and proteasome inhibition, all capable of inducing ER stress.

\section{Material and methods}

Amblyomin-X expression

The recombinant protein was prepared as described elsewhere [35]. 


\section{Cell Culture}

RENCA cells were cultured in RPMI, supplemented with $10 \%$ fetal bovine serum, $0.1 \mathrm{mM}$ of nonessential amino acids, $1 \mathrm{mM}$ of sodium pyruvate, $2 \mathrm{mM}$ of L-glutamine, $100 \mathrm{mg} / \mathrm{mL}$ of streptomycin sulfate and $100 \mathrm{U} / \mathrm{mL}$ of penicillin G. The strain was kindly provided by Dr. Maria Helena Bellini Marumo (Institute of Energy and Nuclear Research-IPEN-in São Paulo, Brazil), wich in turn received from Dr. Isaiah J. Fidler (The University of Texas M. D. Anderson Cancer Center, Houston, TX)[36-38]. It is an epithelial renal cell carcinoma of conventional type, clear cell (ccRCC) from spontaneous tumor growth in renal cortical tissue of mice of the Balb/c tha was isolated in 1969 and established as a cell line in 1973[39]. The NIH3T3 mouse fibroblast cells [ATCC No. CRL-1658] were cultured in DMEM , supplemented with $10 \%$ fetal bovine serum, $100 \mathrm{mg} / \mathrm{mL}$ of streptomycin sulfate and $100 \mathrm{U} / \mathrm{mL}$ of penicillin G. RENCA and NIH3T3 cells were kept at $37{ }^{\circ} \mathrm{C}$ in a $5 \% \mathrm{CO}_{2}$ atmosphere. The medium was changed after $12 \mathrm{~h}$, and then every 3 days.

Cell micromorphological analysis by scanning electron microscopy (SEM)

In order to facilitate protein penetration and precipitation, and ensure optimal preservation of their ultrastructures, RENCA and NIH3T3 cells were fixed with $3 \%$ glutaraldehyde for $24 \mathrm{~h}$. Subsequently, the samples were washed 5 times in a cacodylate buffer, prior to post-fixing in $4 \%$ buffered $\mathrm{OsO}_{4}$ for $1 \mathrm{~h}$, followed by further buffer-washing. Prior to treatment with or without $0.1 \mu \mathrm{M}$ of Amblyomin-X, the cell suspension was centrifuged at $1500 \mathrm{rpm}$ for $5 \mathrm{~min}$, re-suspended in RPMI-1640 supplemented with $10 \%$ FBS, and cultured in $2 \mathrm{~cm}^{2}$ petri dishes at a density of $10^{6}$ cells/ $\mathrm{mL}$. After 24-hours of treatment, the cells were referenced for normal NIH/3 T3 fibroblasts, before transferring to permeable critical-point apparatus for double dehydrating in alcohol baths at 30, 50, 70, 80, 95 and $100 \%$ concentration. Several changes were required to so ensure complete removal of all the water content. Drying of the samples was performed at critical point apparatus using carbon dioxide and the plates received the metallic coating with gold by sputtering. Finished processing the material was observed and analyzed in a Philips XL30 scanning-electron microscope.

Determination of the proteins involved in apoptosis and mitochondrial events by flow cytometry

Flow cytometry was applied to evaluating pro- and antiapoptotic protein expression, cytochrome c measurement, the analysis of mitochondrial membrane potencial, and caspase activation. Accordingly, RENCA and NIH3T3 $5 \times 10^{5}$ cells were placed on 6 -well-plates with a culture medium supplemented with fetal bovine serum. After cell adhesion, Amblyomin-X was added to the cell culture for $24 \mathrm{~h}$, in a final concentration of $0.1 \mu \mathrm{M}$.

So as to assess Bcl-2 family expression and caspase 3 activation, cell concentration was first adjusted to $5 \times 10^{5}$ cells $/ \mathrm{mL}$, whereupon aliquots of $100 \mu \mathrm{L}$ of cell suspension were permeabilized with a solution of Triton X-100 $0.1 \%$ in FACs buffer Flow (BD), and then incubated for $1 \mathrm{~h}$ at $4{ }^{\circ} \mathrm{C}$ with $1 \mu \mathrm{g}$ of either of three specific antibodies, antiBad, anti-Bax or anti-Bcl-2, conjugated with FITC (Santa Cruz, USA), and $1 \mu \mathrm{g}$ of specific antibody anti-Caspase 3 phosphorylated phycoerythrin conjugated-PE (Santa Cruz, USA), in either the presence or absence of its specific AcAsp-Glu-Val-sp-OH inhibitor (BioAgency Biotechnology). Subsequently, the cells were centrifuged for $10 \mathrm{~min}$ at $1500 \mathrm{rpm}$ and washed with cold PBS. The supernatant was discarded, and the cell-button again suspended in PBS containing $1 \%$ of paraformaldehyde. The reading and analysis of expression in arbitrary units of fluorescence of cell surface receptors were performed with a flow cytometer (Becton Dickinson, San Jose, CA, USA).

Cells present in the supernatant, as well as those trypsinized adherent, were transferred to cytometer tubes, and fixed with $4 \%$ paraformaldehyde, in order to evaluate cytochrome c release and p53 expression. Cells were permeabilized with $0.5 \%$ saponin in PBS for $30 \mathrm{~min}$ at room temperature. In sequence, cells were washed with a buffer Fac's flow containing $0.1 \%$ saponin in PBS solution (BSA/saponin), and then incubated with monoclonal antibody anti-cytochrome c (Santa Cruz USA) and anti-p53 (Santa Cruz, USA), at a concentration of $1 \mu \mathrm{g}$ of antibody per $10^{6}$ cells, during $18 \mathrm{~h}$ at $4{ }^{\circ} \mathrm{C}$. They were then washed with BSA/saponin and incubated with a secondary antibody conjugated with phycoerythrin-PE $(1 \mu \mathrm{g})$. After incubation for $2 \mathrm{~h}$ at $37{ }^{\circ} \mathrm{C}$, they were again washed with PBS and fixed in $1 \%$ paraformaldehyde. Accompaniment throughout the whole process was done by isotype control.

Electric potential was assessed by mitochondrial effluxing of fluorescent probe Rhodamine-123, with a functional MDR phenotype as control. Briefly, $300 \mu \mathrm{L}$ of cell suspension were incubated with or without Rhodamine-123 probe $(200 \mathrm{ng} / \mathrm{mL})$ in a humidified $5 \% \mathrm{CO} 2$ incubator for $45 \mathrm{~min}$ at $37^{\circ} \mathrm{C}$. After centrifugation for $30 \mathrm{~min}$ at $1500 \mathrm{rpm}$, the cells were washed in cold PBS, and mitochondrial potential measured with a flow cytometer. Histograms of fluorescence intensity were obtained from the gates of cells tested. The results were analyzed as mean fluorescence intensity (MFI), by MFI ratio of the sample under study and its negative control. In this study, $1 \times 10^{4}$ cells per sample were analyzed with Cell Quest (BD) version 3.1, and FSC (size) and SSC 
(granularity/complexity) FL1/FL2 as parameters, to evaluate fluorescence intensity of the binding reaction antigen/antibody conjugated to PE and/or FITC. All acquisitions were done in three independent experiments.

\section{Proteasome activity}

Proteassome activity was determined according to Chudzinski et al. [34]. RENCA and NIH3T3 cells were treated with $0.1 \mu \mathrm{M}$ of Amblyomin-X for two periods of 4 and $16 \mathrm{~h}$. The cells were then washed twice with PBS and mechanically lysed. After quantification of total proteins in the cell extract, aliquots of 15-30 $\mu \mathrm{g}$ were separated for measuring proteasome activity. Fluorogenic peptides (AMC, 7-amide4-methylcoumarin; Calbiochem, San Diego, CA, USA) were used to determine proteasomal activity, Suc-LLVY$\mathrm{AMC}$, the standard peptide for assessing chymotrypsinlike activity and z-ARR-AMC, was used to determine trypsin-like activity. The cell extracts obtained were incubated at $37{ }^{\circ} \mathrm{C}$ with $125-500 \mathrm{mM}$ of fluoropeptides. Fluorescence emission at $440 \mathrm{~nm}$ (excitation at $365 \mathrm{~nm}$ ) was recorded for $1 \mathrm{~h}$. The calculation of final results, expressed as the percentage of hydrolysis measured in total extracts from untreated control cells, was based on the difference between total cell-extract hydrolytic activity, and the activity determined in samples previously incubated with standard proteasome inhibitors (lactacystin or NLVS). All the experiments were carried out in triplicate.

\section{Calcium measurement by confocal microscopy}

Before measuring changes in $\left[\mathrm{Ca}^{2+}\right]_{i}$ levels in RENCA cells by calcium imaging with a LSM 510 Meta confocal microscope (Zeiss, Jena, Germany), $2.5 \times 10^{5}$ cells were seeded and attached to cover slides in p60-mm culture dishes (Nalge Nunc International, Rochester, NY), prior to pretreatment with $0.5 \mu \mathrm{M}$ of Amblyomin-X at intervals of 5 and $24 \mathrm{~h}$. After loading for $30 \mathrm{~min}$ at $37^{\circ} \mathrm{C}$ with $4 \mu \mathrm{M}$ Fluo3 AM (Sigma Chemical, St. Louis, MO) in the presence of $0.5 \% \mathrm{Me} 2 \mathrm{SO}$ and $0.1 \%$ of the nonionic surfactant pluronic acid F-127, the cells were then washed three times with DMEM containing $10 \%$ FBS. Fluo-3 AM fluorescence excitation was done by Argon ion laser at $488 \mathrm{~nm}$, with fluorescence-emission collection at $510-530 \mathrm{~nm}$ with a band-pass filter. The changes in $\left[\mathrm{Ca}^{2+}\right]_{i}$ levels were recorded every $10 \mathrm{~s}$. After reading each sample, a 4-Br-A23187 ionophore $(5 \mu \mathrm{M})$ and an EGTA chelating compound $(10 \mathrm{mM})$ were used to determine maximal (Fmax) and minimal (Fmin) fluorescence values, respectively. Intracellular free-calcium concentrations were calculated from relative fluorescence values by using the equation $\left[\mathrm{Ca}^{2+}\right]_{i}=\mathrm{Kd}$ $(\mathrm{F}-\mathrm{Fmin}) /(\mathrm{Fmax}-\mathrm{F})$, assuming $450 \mathrm{nM} \mathrm{Kd}$ for fluo-3 calcium binding [40].
Gene expression analysis related to ER stress response by real-time PCR

Polymerase chain reaction (PCR) was applied to real time quantitative expression analysis of those genes related to ER-stress response. cDNA strands were constructed with total RNA extracted from RENCA cells, using a cDNA Cycle Kit for RT-PCR kit (Invitrogen ${ }^{\mathrm{TM}}$, Life Technologies Inc.), according to manufacturer's instructions. Specific primers were used in the formation of double-stranded cDNA. The StepOne Plus Real-Time PCR System (Applied Biosystems, Foster City, CA, USA) was applied to cDNA amplification. Specific double-tranded DNA was labeled with SYBR Green I provided in the SYBR Green PCR Master Mix (Invitrogen ${ }^{\mathrm{TM}}$, Life Technologies Inc.), to so facilitate quantitative detection of PCR products in a reaction volume of $25 \mu \mathrm{L}$. The PCR procedure was an initial $10 \mathrm{~min}$ at $95^{\circ} \mathrm{C}$, followed by 40 cycles of denaturation of $15 \mathrm{~s}$ at $95^{\circ} \mathrm{C}, 30 \mathrm{~s}$ at $60^{\circ} \mathrm{C}$, and finally $30 \mathrm{~s}$ at $72{ }^{\circ} \mathrm{C}$. The GAPDH (Glyceraldehyde-3-phosphate dehydrogenase) gene expression level was used to normalize differences in RNA isolation and degradation. The results were analyzed by relative quantification between groups: control, using $2^{-\Delta \Delta \mathrm{CT}}[41]$.

Determination of GRP78 and GADD153 protein expression by Western blot

RENCA cells were grown in an appropriate medium until reaching $80 \%$ confluence. Once stabilized, the culture medium was replaced, whereupon the cells were stimulated with $0.5 \mu \mathrm{M}$ of Amblyomin-X for periods of 2, 6 or $24 \mathrm{~h}$. They were then lysed with a RIPA buffer $(1 \%$ deoxycholate, $150 \mathrm{mM}$ of $\mathrm{NaCl}, 1 \% \mathrm{SDS}, 10 \mathrm{mM}$ of $\mathrm{NaF}, 1 \%$ Triton $\mathrm{X}-100,50 \mathrm{mM}$ of Tris- $\mathrm{HCl}$ ), together with the protease inhibitors, aprotinin $(2 \mathrm{mg} / \mathrm{mL})$, fenilmetilsulfonilfluoreto (PMSF) $(1 \mathrm{mM})$, and orthovanadate phosphatase $(1 \mathrm{mM})$. The resultant products were then incubated on ice for $20 \mathrm{~min}$. After protein quantitation by the bicinchoninico acid (BCA) method, using BSA as standard protein curve, $30 \mu \mathrm{g}$ from each sample underwent electrophoresis on $10 \%$ SDS gel, prior to transferring to a PVDF membrane (Hydrophobic polyviniylidene difluoride, Healthcare, USA), using as transfer buffer $0.25 \mathrm{M}$ Tris, $0.19 \mathrm{M}$ glycine and $20 \%$ methanol, under a constant voltage of $100 \mathrm{~V}$ for $1 \mathrm{~h}$ at $4{ }^{\circ} \mathrm{C}$. In order to block nonspecific sites, the membrane was incubated three times, first with a solution of $5 \% \mathrm{BSA}$ in TBS-Tween $(20 \mathrm{mM}$ of Tris- $\mathrm{HCl} \mathrm{pH} 7.4,0.15 \mathrm{M}$ of $\mathrm{NaCl}$ and $0.2 \%$ Tween), then with the primary antibodies antiGRP78 1:1000 (Santa Cruz Biotechnology Inc, CA, USA) and anti-GADD153 1:200 (Santa Cruz Biotechnology Inc, CA, USA), using as internal control anti-GAPDH 1:5000 (Sigma Aldrich, MO, USA), and finally with an HRP- 
conjugated secondary antibody (Sigma-Aldrich, MO, USA). Immunostaining was revealed with an ECL solution and detected by LAS4000 ImageQuant equipment (EG, Germany). An Amersham Rainbow Full-Range molecular weight marker (GE Healthcare, USA), was used for comparing the position of the bands on the gel in use. The ImageJ analysis program (National Institute of Health, USA) was used for quantification of the bands thus found.

\section{Determination of $\mathrm{NO}$ and $\mathrm{H}_{2} \mathrm{O}_{2}$ production}

In order to determine NO production, $1 \times 10^{5}$ RENCA cells were seeded onto 96-well-plates for posterior treatment with $0.1 \mu \mathrm{M}$ of Amblyomin-X during $48 \mathrm{~h}$. NO production was monitored in the extracellular medium by assessing nitrite levels with a Griess reagent. Briefly, $50 \mu \mathrm{L}$ of cell-free supernatants were added to $100 \mu \mathrm{L}$ of Griess reagent (5 \% H3PO4, $1 \%$ sulfanilamide, $0.1 \% \mathrm{~N}-1$-naphtylethylendiamine). Absorbance was measured at $540 \mathrm{~nm}$. Various concentrations of sodium nitrite were used in the construction of a standard curve. All biochemical analyses were performed in triplicate.

The assessment of $\mathrm{H}_{2} \mathrm{O}_{2}$ levels by microassaying, using a technique described and adapted by Pick and Mizel [42], consisted of the following. $2 \times 10^{5}$ cells $/ \mathrm{mL}$ of adherent RENCA cells was suspended in $1 \mathrm{~mL}$ of RPMI-1640. $100 \mu \mathrm{L}$ of the so formed suspension were placed into flatbottomed 96-well culture plates. In order to induce cell adhesion, the plates were incubated for $1 \mathrm{~h}$ at $37^{\circ} \mathrm{C}$ in a humidified atmosphere $\left(5 \% \mathrm{CO}_{2}\right)$. The wells were then washed with PBS to remove non-adherent cells. A phenol red solution was then added, prior to $\mathrm{H}_{2} \mathrm{O}_{2}$ assaying. This was followed by incubation at $37{ }^{\circ} \mathrm{C}$ in a humid atmosphere for $1 \mathrm{~h}$. The reaction was stopped by adding $1 \mathrm{~N}$ sodium hydroxide $(\mathrm{NaOH})$. The tests were done in quadruplicate. Control samples, without PMA stimulation, were simultaneously evaluated to assess the spontaneous production of $\mathrm{H}_{2} \mathrm{O}_{2}$. Absorbance was determined by way of an ELISA reader with a $620 \mathrm{~nm}$ filter, to thus obtain optical density (OD). The results are presented in nmols of $\mathrm{H}_{2} \mathrm{O}_{2}$.

\section{Statistical analysis}

For comparative analysis of the two groups, treated or untreated with Amblyomin-X, statistical significance was determined by one- or two-way variance analysis (ANOVA) followed by Bofferoni correction, as well as the Tukey-Kramer or Dunnett post-tests, using GraphPad Prism 5.0 software (GraphPad Software Inc., San Diego, CA). The criteria for statistical significance, set at $P<0.05$, were represented by an asterisk $(*)$. Data are expressed as mean \pm SEM.

\section{Results}

Morphological apoptosis characteristics were observed in RENCA cells treated with Amblyomin-X

RENCA cells treated with Amblyomin-X presented morphological differences when compared to those un-treated (Fig. 1). In the control group, a novel cell structure was formed, through the expansion of a central condensed part into long, branched structures projecting from cytoplasmic interconnections and expansions of the cytoplasm and the cytoskeleton (Fig. 1). In contrast, the group treated with Amblyomin-X presented striking morphological changes, characteristic of cells undergoing apoptosis, with apoptotic body formation, the reduction of microvilli, loss of adhesion to the matrix, and formation of membrane blebs. There is no organization of the extracellular matrices, but appreciable morphological changes, such as the formation of round cells and cell debris (Fig. 1). Interestingly, NIH3T3 cells in both the control and treated groups showed the same pattern of cell morphology, with the presence of fibroblastoid spindle cells, adhered to the contact surface of the culture plate, and the formation of three-dimensional fiber and fibril highdensity networks connecting the external surfaces of cells with cytoplasmic projections to adjacent cells. Furthermore, there were no morphological modifications, such as cell rounding or debris, and the well-preserved extracellular matrix was juxtaposed between firmly adhered cells and those recently proliferated. Moreover, cell division was clearly visible (Fig. 1).

Amblyomin-X affects the balance between pro-apoptotic and anti-apoptotic proteins and mitochondrial integrity

Analysis of Bcl-2 family expression levels by flow cytometry revealed that treatment with $0.1 \mu \mathrm{M}$ of Amblyomin-X induces imbalance between pro- and anti-apoptotic proteins in RENCA, but not in NHI3T3 cells. After $24 \mathrm{~h}$ of Amblyomin-X treatment, there was a significant change in protein expression levels, with an approximate 6-fold reduction in anti-apoptotic Bcl-2 proteins, and a 3.5-fold increase in Bax and Bad (Fig. 2a, b and c). However, no changes were observed in p53 expression levels in either RENCA or NIH3T3 cells (Fig. 3), an indication that this protein is not involved in the regulation of either expression or cytoplasmic activation in the Bcl-2 family.

As these proteins play a role in the maintenance of mitochondrial integrity, and since dysfunction has been noted, it was decided to investigate whether changes in Bcl-2 family expression levels were accompanied by changes in mitochondrial potential. Thus, by using the same concentration of Amblyomin- $X$ and the same treatment period, it was observed that Amblyomin-X was capable of 
Fig. 1 Morphological

differences between RENCA and NIH3T3 cells treated

with Amblyomin-X. Photomicrographs of cells treated with $0.1 \mu \mathrm{M}$ of Amblyomin-X for $24 \mathrm{~h}$, and untreated ones (control), observed and analyzed by SEM. (RENCA Control) Details of extracellular matrix organization. (RENCA Amblyomin-X) Apoptotic bodies and cell-membrane disruption. (NHI3T3 Control)

Spindle cells, extracellular matrix organization and fibrillar collagen arrangement.

(NHI3T3 Amblyomin-X)

Fibroblastoid cells adhered to the surface and extracellular matrix organization
Control

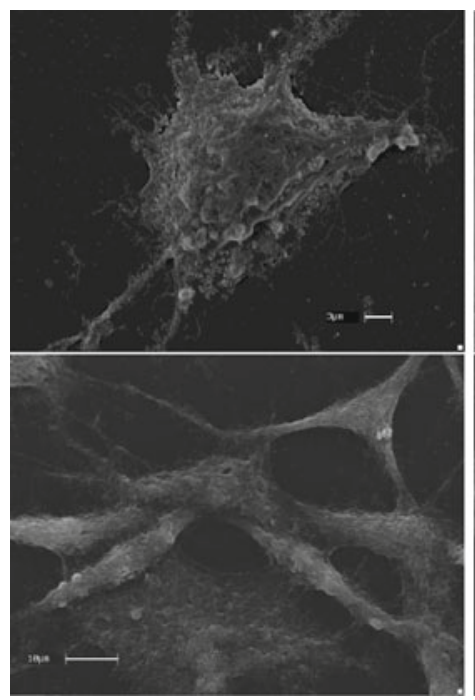

Amblyomin-X

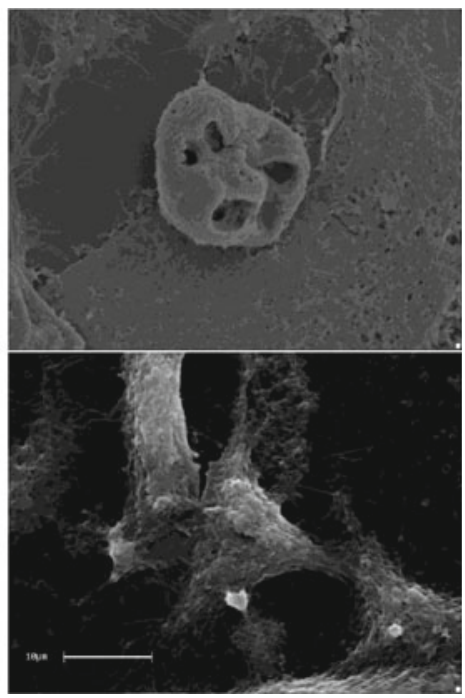

significantly reducing the mitochondrial potential in both adherent RENCA cells and those present in the supernatant, with no changes in NHI3T3 cells (Fig. 2d). Contributing to this result, there was an approximate 3-fold increase in the release of cytochrome c into the cytosol in RENCA cells treated with Amblyomin-X, when compared to control group. This was not observed in NHI3T3 cells, where no changes in cytochrome c release were observed (Fig. 2e).

The effect of Amblyomin-X on caspase 3 catalytic activity

Caspase 3 catalytic activity in RENCA and NHI3T3 cells was evaluated after a 24-hour-treatment with $0.1 \mu \mathrm{M}$ of Amblyomin-X. The proportion of caspase 3 phosphorylation and activation by Amblyomin-X in RENCA cells was about 7 times higher than in the control group (Fig. 4). This could arise from the observed cytochrome c release (Fig. 2e). On the other hand, no like difference was observed in either treated or untreated NHI3T3 cells (Fig. 4).

\section{Proteasome inhibition by Amblyomin-X}

Previous studies have shown that Amblyomin-X is capable of negatively modulating proteasome activity in SK-Mel-28 and Mia-Paca- 2 tumor human strains, through preferentially inhibiting the trypsin-like site and increasing the pool of poly-ubiquitinated proteins [34]. This strongly implies that this activity could be an Amblyomin-X target for triggering cytotoxic effects. Results obtained with RENCA cells showed that 4 and $16 \mathrm{~h}$ after treatment with $0.1 \mu \mathrm{M}$ Amblyomin-X, there was a significant decrease in chymotrypsin-like proteasome activity (Fig. 5). After $16 \mathrm{~h}$ of incubation, the reduction was 4-fold, when compared to controls.
Amblyomin-X-induces ER stress in RENCA cells

On seeking to correlate the effects of Amblyomin-X on proteasome functions and ER stress in RENCA cells, it was decided to evaluate whether this molecule was capable of causing ER stress. Hence, its capacity to interfer with $\left[\mathrm{Ca}^{2+}\right]$ and the expression of targets related to ER stress, was analyzed.

Through microfluorimetry, the increase in $\left[\mathrm{Ca}^{2+}\right]_{i}$ was instantaneous, although not transient, in Amblyomin-X treated RENCA cells, suggesting an induced calcium homeostasis disturbance. For instance, immediately after applying of $0.1 \mu \mathrm{M}$ of Amblyomin-X, there was a change in the pattern of fluorescence, without the peak response reaching a maximum (data not shown). Thus, in order to assess $\left[\mathrm{Ca}^{2+}\right]_{i}$ mobilization after longer periods of treatment, quantification by confocal microscopy was resorted to, whereby it was possible to visualize the fluorescence of cells pre-incubated with Amblyomin-X and treated with Fluo-3 AM (Fig. 6a). The analysis of $\left[\mathrm{Ca}^{2+}\right]_{i}$ elevation during Amblyomin-X treatment, revealed that after 5 and $24 \mathrm{~h}$, there was a significant increase - about three- and five-fold, respectively - in the amount of free ions, when compared to control. Nevertheless, on comparing 5-hour and 24-hour treatments, there was no significant difference indicating that Amblyomin-X had reached its maximum response.

The capacity of Amblyomin-X to affect gene expression of targets related to ER stress pathways was tested through real-time PCR. Interestingly, after treating RENCA cells with $0.5 \mu \mathrm{M}$ of Amblyomin-X for $2 \mathrm{~h}$, a significant reduction of around $30 \%$ in mRNA GRP78 levels occurred, followed by a pronounced increase in expression after 6 and $24 \mathrm{~h}$, of 30 and $80 \%$, respectively (Fig. 6b). A similar pattern was observed for the GADD153 gene expression, with a $12 \%$ reduction in expression after $2 \mathrm{~h}$ of treatment, and an increase of about $15 \%$ and $100 \%$ after 6 and $24 \mathrm{~h}$, respectively, without any significant difference (Fig. 6b). 

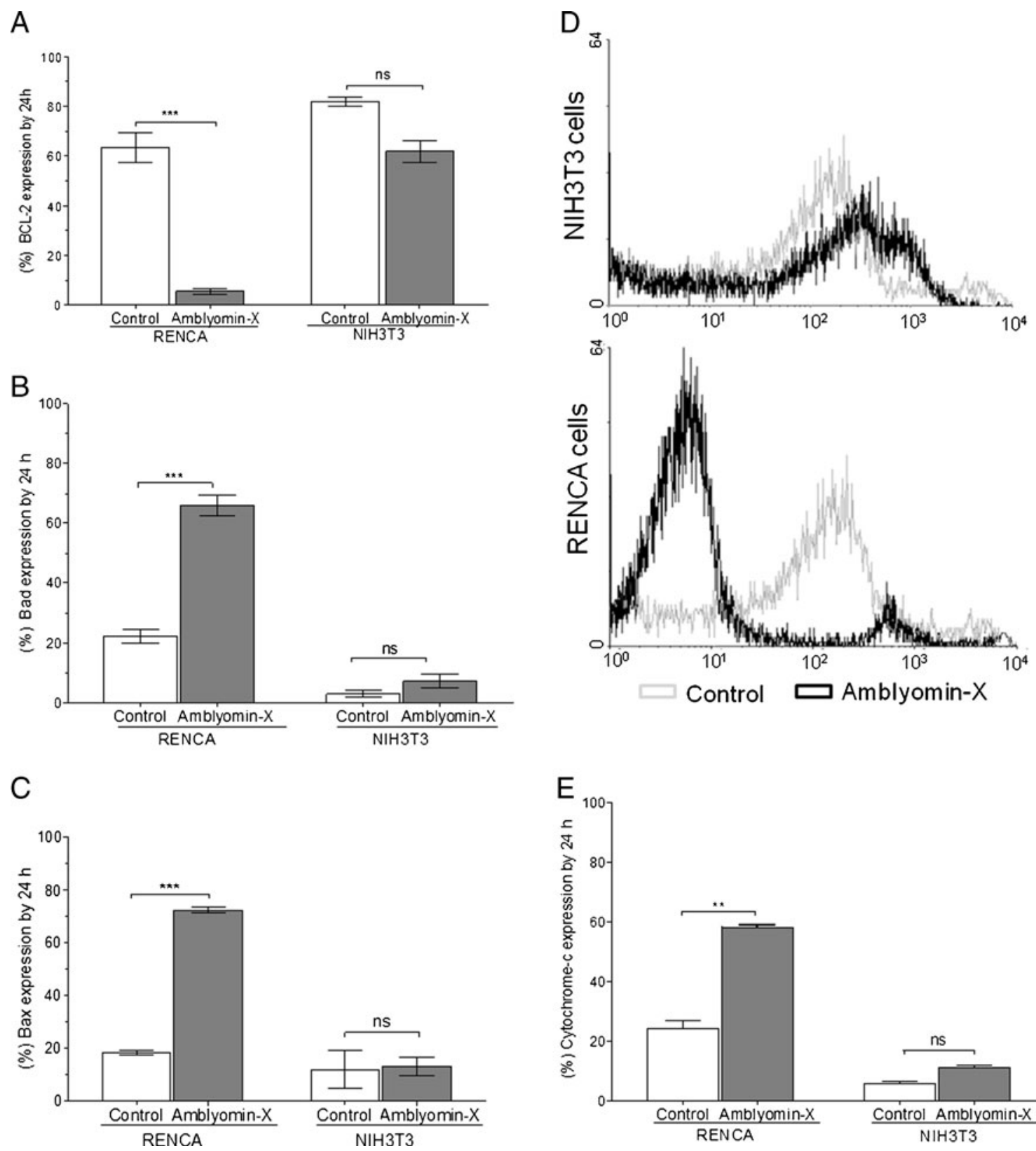

Fig. 2 Imbalance between pro-and anti-apoptotic Bcl-2 family proteins, accompanied by mitochondrial function impairment, is caused by Amblyomin-X. RENCA and NHI3T3 cells were treated with $0.1 \mu \mathrm{M}$ of Amblyomin-X during $24 \mathrm{~h}$. a Bcl-2 expression. b Bad

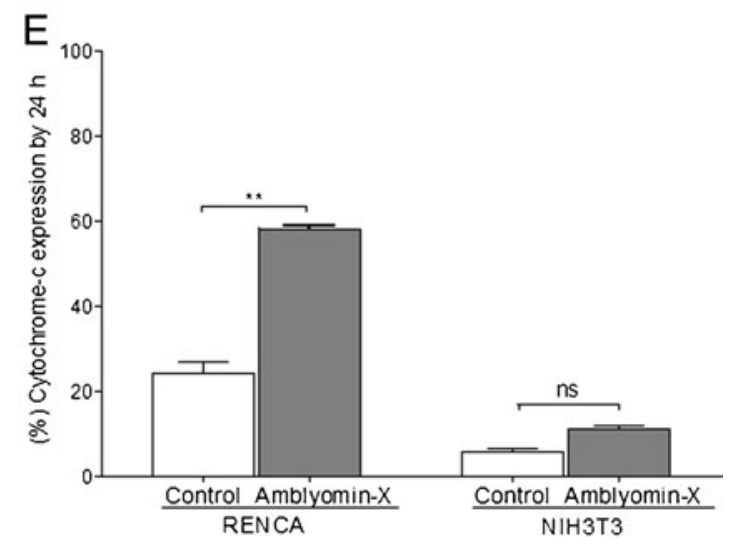

expression. c Bax expression. d Representative histograms of mitochondrial membrane potential. e Release of cytochrome c. Experimentmonitoring was by flow cytometry. The data are presented as mean \pm SEM. $* P<0.05$ vs. control

It was thus indicated that ER is involved in the mechanism of Amblyomin-X action, although it was not clear whether this was through GRP78 reduction or ER stress. Thus, it was decided to assess the levels of GRP78 and GADD153 protein expression under the same conditions of real-time PCR. A correlation between gene and protein expression became apparent. After $24 \mathrm{~h}$ of treatment with Amblyomin-X, there was a $70 \%$ increase in GRP78 protein levels, compared to untreated cells (Fig. 6c and d). Moreover, although GADD153 protein levels decreased in

the interval between 2 to $6 \mathrm{~h}$, this was followed by a significant increase of about $235 \%$ in treated cells after $24 \mathrm{~h}$ (Fig. 6c and e). Thapsigargin was used for $6 \mathrm{~h}$, as positive control at $0.5 \mu \mathrm{M}$.

Modulation of $\mathrm{NO}$ and $\mathrm{H}_{2} \mathrm{O}_{2}$ production by Amblyomin-X

The production of $\mathrm{NO}$ and $\mathrm{H}_{2} \mathrm{O}_{2}$ in RENCA cells was analyzed along the same lines followed in the experiments with $\mathrm{Ca}^{2+}$ and the expression of targets related to ER stress. 


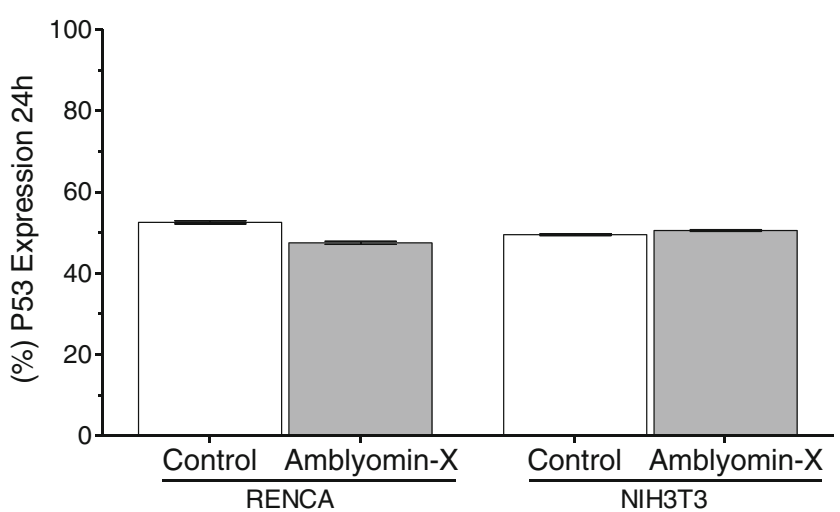

Fig. 3 Amblyomin- $X$ action is p53 independent. RENCA and NHI3T3 cells were treated with $0.1 \mu \mathrm{M}$ of Amblyomin-X during $24 \mathrm{~h}$. Experiment-monitoring was performed by flow cytometry. The data are presented as mean \pm SEM. ${ }^{*} P<0.05$ vs. control

After $48 \mathrm{~h}$ of $0.1 \mu \mathrm{M}$ Amblyomin-X treatment, there was a reduction of $40 \%$ in $\mathrm{NO}$ production, when compared to untreated cells (Fig. 7a), and after $24 \mathrm{~h}$, a $44 \%$ increase in $\mathrm{H}_{2} \mathrm{O}_{2}$ levels (Fig. 7b), thereby indicating that changes in oxidative conditions of RENCA cells treated with Amblyomin-X induced ROS production.

\section{Discussion}

Cell death and survival are topics under constant discussion in scientific literature, however, it has become increasingly evident that these processes are regulated by a sophisticated balance between pro- and anti-apoptotic proteins and highly dynamic interactions that lead cells to a final destination $[43,44]$. Hence, the present study demonstrated that Amblyomin-X promotes apoptotic morphological characteristics into tumor cells, accompanied by imbalance between the protein levels of Bcl-2 family members by decreasing

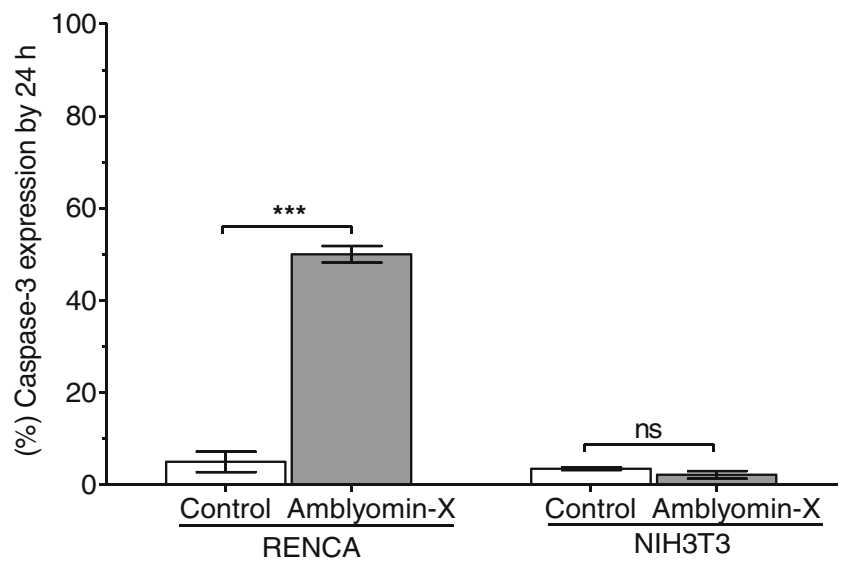

Fig. 4 Amblyomin-X induces caspase 3 activation. Detection of phosphorylated caspase- 3 by flow cytometry in RENCA and NHI3T3 cells treated with $0.1 \mu \mathrm{M}$ of Amblyomin-X during $24 \mathrm{~h}$. The data are presented as mean \pm SEM. $* * * P<0.0005$ vs. control

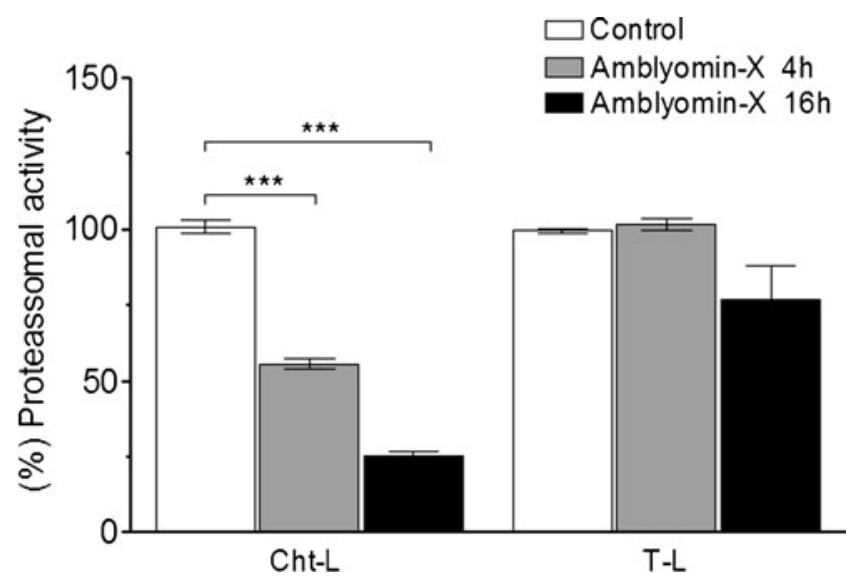

Fig. 5 Inhibition of proteasome activity by Amblyomin-X. RENCA cells were treated with $0.1 \mu \mathrm{M}$ Amblyomin-X for 4 and $16 \mathrm{~h}$, as indicated. ChT-L and T-L proteasomal activities were defined in the cell extracts, as described in Material and Methods. Results shown are expressed as percentages of control samples. ChT-L, chymotrypsinlike and T-L, trypsin-like activities, respectively. The data are represented as mean \pm SEM. $* * * P<0.0005$ vs. control

anti-apoptotic and increasing pro-apoptotic levels, without p53 participation. Interestingly, there are several clinical and preclinical anti-tumor drugs, for example, ABT-737, that target members of the Bcl-2 family, and many studies argue that the reduction of Bcl-2 and Bcl-XL would be sufficient to induce cell apoptosis $[13,45,46]$.

Mitochondria are also predominant target in the search for novel anti-tumor therapies. Accordingly, interest has recently been focused on a new class of drugs, the mitocans, which act through tumor cell mitochondria, without affecting normal ones [47, 48]. The mechanism of their action is based on the ability to disrupt cellular energy production systems by way of mitochondria, thereby leading to an increase in reactive oxygen species and the activation of cell death by signaling mitochondria dependent pathways. Apart from their efficacy, these drugs have become additionally attractive through presenting few side effects on normal cells in in vivo experiments [48]. These characteristics were observed in tumor cells treated with Amblyomin$\mathrm{X}$, by compromising the mitochondrial membrane potential, the release of cytochrome c, and the increased production of ROS, observed by an increase in $\mathrm{H}_{2} \mathrm{O}_{2}$ levels. These results suggest, thereby, that these responses can lead to caspase 3 activation, ultimately culminating in apoptosis.

Apparently, Amblyomin-X induces ER stress by negatively modulating proteasome activity. This is characterized by an increase in the concentration of free intracellular $\mathrm{Ca}^{2+}\left(\left[\mathrm{Ca}^{2+}\right]_{i}\right)$, and changes in GRP78 and GADD153 protein levels, considered classical markers of the process. Proteasome inhibition can also lead to the accumulation of proteins bearing conformational- 


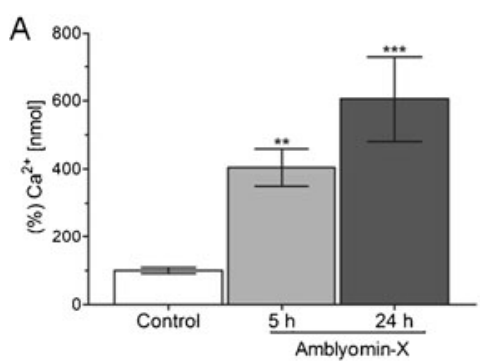

B

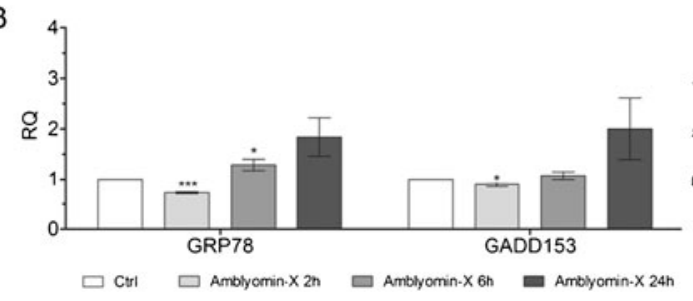

Fig. 6 Amblyomin-X induces ER stress in RENCA cells. a Through confocal microscopy - the graphical representation of $\mathrm{Ca}^{2}+$ quantitative influx in unstimulated cells, and RENCA cells stimulated with $0.5 \mu \mathrm{M}$ Amblyomin-X for 5 and $24 \mathrm{~h}$. b By real-time PCR-levels of gene expression of targets related to ER stress. Cells were treated with $0.5 \mu \mathrm{M}$ of Amblyomin-X for 2, 6 and $24 \mathrm{~h}$. c Western blot analysis of

structure damage, a condition which can lead to ER stress [29, 30, 49]. Cell response consists of the release of $\mathrm{ER} \mathrm{Ca}^{2+}$ stores, which is either taken up by mitochondria, or directed to other intracellular destinations, thereby activating a signaling cytoprotective response, denominated 'unfolded protein response' (UPR) [50]. One of the characteristic effects of UPR is translational attenuation, a form of reducing new-protein synthesis, and so avoiding the accumulation of proteins with conformational defects. This is accomplished by phosphorylation of the eIF $2 \alpha$, an event that redirects transcript alternative targets, such as chaperones (e.g., GRP78), and proteasome subunits [32]. However, if UPR is suppressed by sustained proteasome inhibition, stress can lead to severe and prolonged ER-activating death pathways $[25,51]$. In parallel, the induction of transcription
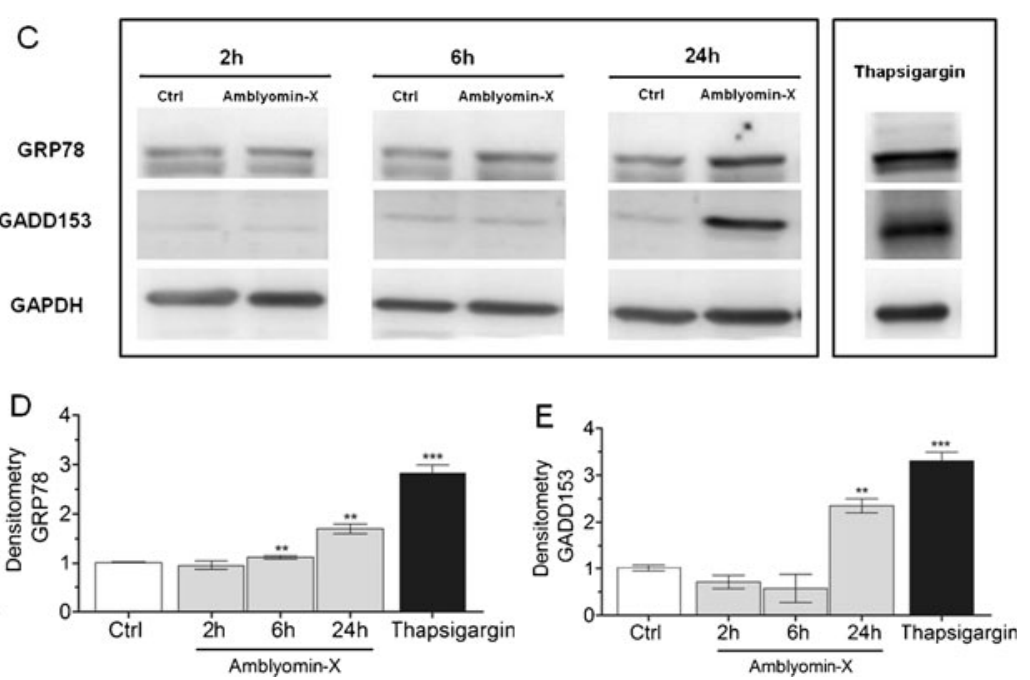

samples with or without treatment (Ctrl) using anti-GRP78, antiGADD153 and anti-GAPDH, as endogenous controls. $\mathbf{d}$ and $\mathbf{e}$ Densitometry analysis of protein bands revealed with anti-GRP78 and anti-GADD153 relative to control. Values are mean \pm SD of three independent experiments. $* P<0.05$ compared to control (untreated cells)

factors, such as pro-apoptotic growth arrest and DNA gene product GADD153, may also occur. GADD153 is a nuclear transcription factor that represses $\mathrm{Bcl}-2$ promotors, and is capable of sensitizing mitochondria to the pro-apoptotic effects of $\mathrm{BH} 3$-only proteins. Its overexpression can lead to cell-cycle arrest and apoptosis [52]. GADD153 expression, mainly regulated at the transcriptional level, is one of the most highly induced during ER stress [52].

There appear to be several anti-tumors, such as curcumin, salubrinal, bortezomib and sorafenib, whose individual action are similar of Amblyomin-X mechanism, by inhibiting proteasome activity and causing ER stress [23, 24, 29, 53]. Similarly, some of these drugs act selectively on tumor cells. There is some discussion to explain this phenomenon, i.e., cycling cells are possibly

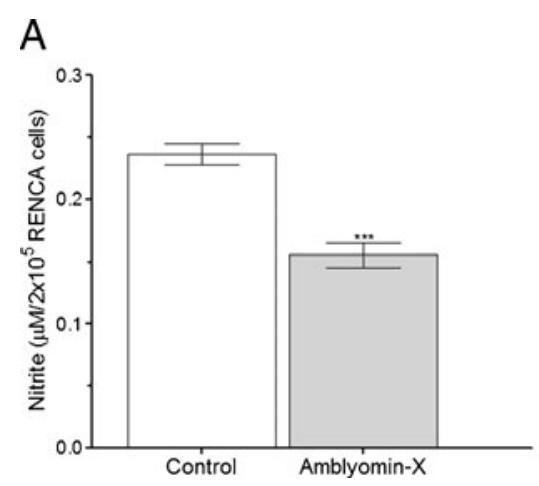

Fig. 7 Changes in oxidative conditions of RENCA cells in the presence of Amblyomin-X. a NO levels in RENCA cells treated with $0.1 \mu \mathrm{M}$ of Amblyomin-X for $48 \mathrm{~h}$. b $\mathrm{H}_{2} \mathrm{O}_{2}$ levels in RENCA cells

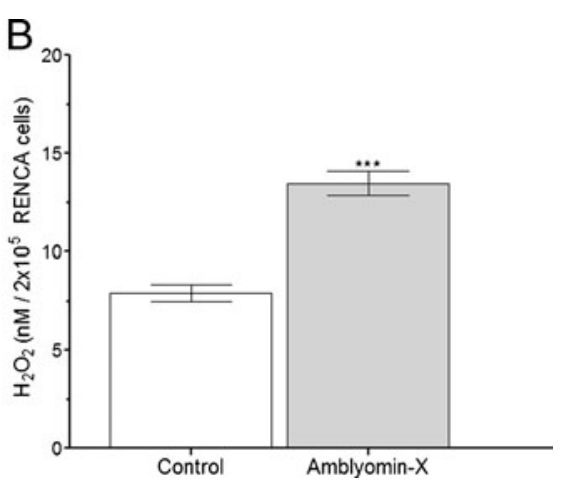

treated with $150 \mathrm{nM}$ of Amblyomin-X for $24 \mathrm{~h}$. The values are the mean \pm standard deviation of three independent experiments. ${ }^{*} P<0.05$ vs. control 
more sensitive to proteasome inhibition than resting ones. This is probably due to so many crucial cellcycle checkpoints being regulated by proteasome activity, or by displaying a higher baseline rate of translation compared to other cells. This could make them more vulnerable to protein buildup, and the subsequent ER stress caused by proteasome activity. Even so, as yet, nothing is conclusive [23, 24, 29, 53].

Apparently, there is an interrelationship between mitochondrial dysfunction, ROS production, and ER stress. Mitochondrial dysfunction and ER stress are capable of producing ROSs, or even inducing the establishment of such cell conditions [54]. ER stress and ROS production also play a role in the modulation of $\mathrm{Bcl}-2$ family proteins, as well as inducing mitochondrial damage [9, 55]. For example, as shown here, the Amblyomin-X induced increase in $\mathrm{H}_{2} \mathrm{O}_{2}$ and decrease in NO levels are both related to $\mathrm{Bcl}-2$ protein instability and deactivation. Concomitantly, the $\mathrm{Bcl}-2$ pro-apoptotic protein family can initiate apoptosis via ER, thereby directly affecting $\mathrm{Ca}^{2}+$ stocks and caspase-12 activation [54-57]. It was found that proteasome inhibition (4 and $16 \mathrm{~h}$ of treatment) and responses related to ER stress, such as changes in gene expression of ER stress marker proteins and $\left(\mathrm{Ca}^{2}{ }^{+}\right)_{i}$ levels, were observed earlier (between 5 and $6 \mathrm{~h}$ of treatment), than responses related to mitochondrial damage, such as, cytochrome c release and ROS production ( $24 \mathrm{~h}$ of treatment). This presupposes Amblyomin-X begins pro-apoptotic signaling by way of ER stress. Notwithstanding, there is no way of ruling out the possibility of this molecule activating these pathways separately, and that their individual cellular response converge in

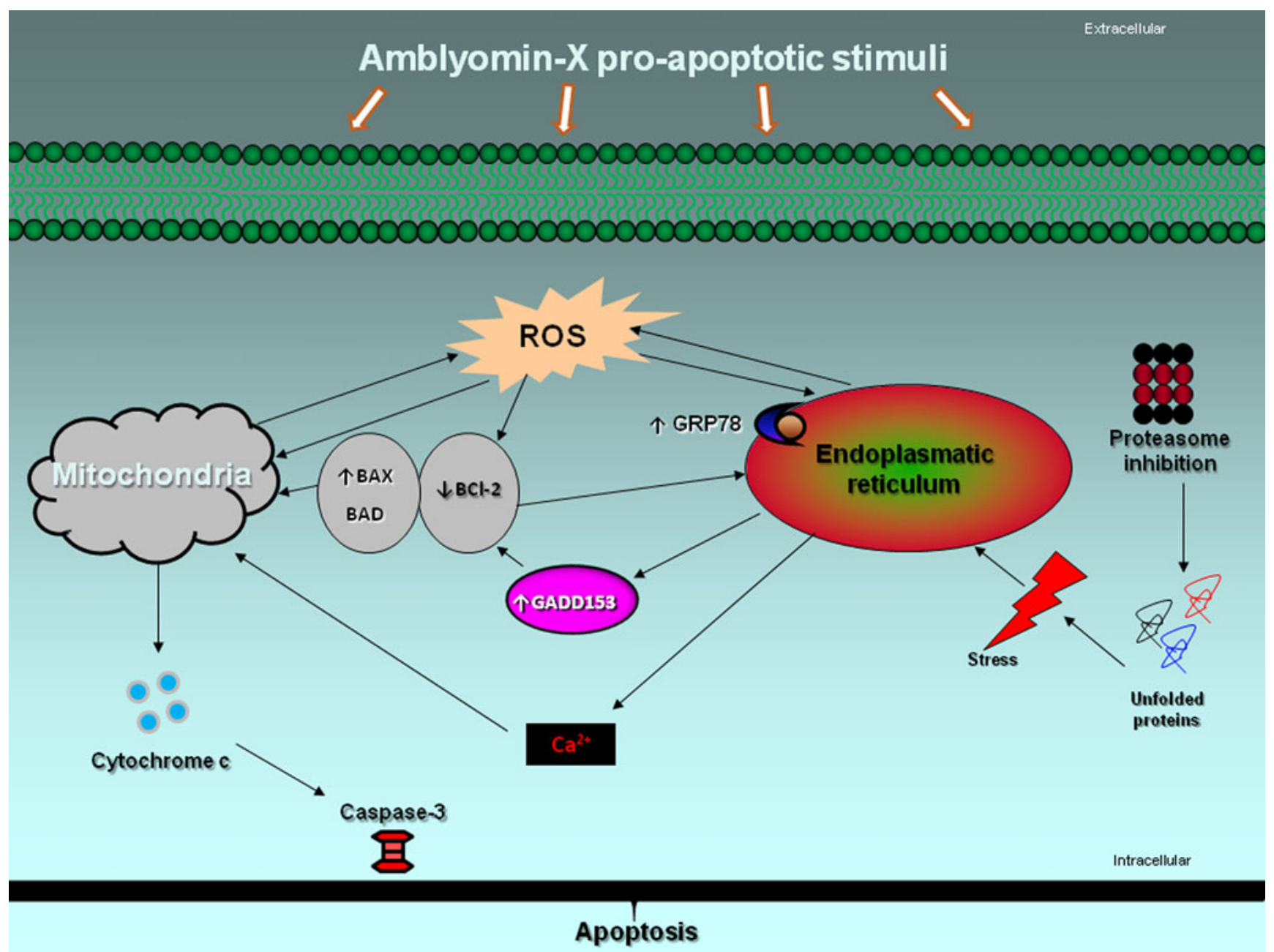

Fig. 8 Possible mechanisms involved in Amblyomin-X pro-apoptotic action in RENCA cells. Amblyomin-X causes: (i) protein imbalance between pro- and anti-apoptotic Bcl-2 family proteins; (ii) mitochondrial dysfunction, marked by changes in its membrane potential and release cytochrome c; (iii) activation of caspases, (iv) proteassomal inhibition; (v) ER stress, characterized by induced expression in the respective protein markers (GRP78 and GADD153) and changes in $\left(\mathrm{Ca}^{2+}\right)$ levels. Hypothetically, Amblyomin-X could act separately in these cell pathways responses, or even synergistically between them, converging in apoptosis. Nevertheless, more conclusive studies are required to confirm this hypothesis (adapted from [9, 33, 54-57]) 
apoptosis, or proceed until reaching the point of synergy between the pathways (Fig. 8). Novel experimental approaches are required to confirm this hypothesis.

\section{Conclusions}

Amblyomin-X is an FXa inhibitor of the Kunitz-type that has anti-tumor activity. Even so, the cell-events triggered by this molecule have not, as yet, been finally defined. Nevertheless, its apoptotic effect on RENCA cells is hereby confirmed. This effect comprises: (a) induces protein imbalance between proand anti-apoptotic Bcl-2 family proteins; (b) mitochondrial dysfunction, marked by changes in its membrane potential and release of cytochrome c; (c) caspase 3 activation, (d) proteasomal inhibition; (e) ER stress, characterized by the induction of specific protein marker expression (GRP78 and GADD153) and changes in $\left(\mathrm{Ca}^{2+}\right)_{i}$ levels (Fig. 8). In view of its selective action on tumor cells, since no significant change was observed in NIH3T3 cells treated with Amblyomin-X, and of the current efforts to develop effective cancer-combat therapies, these results are relevant to understanding the Amblyomin-X mechanism of action, and to its appointment as an effective therapeutic agent candidate.

Acknowledgement We would also like to thank the technician Alexsander Seixas de Souza, Laboratório de Parasitologia, Instituto Butantan, for help in experiments where the Zeiss LSM-510 Meta Confocal Microscope was required. This work was supported by Fundação de Amparo à Pesquisa do Estado de São Paulo (FAPESP 2010/52669-3 and CAT/CEPID - 1998/14307-9), União Quimica Farmacêutica Nacional, Conselho Nacional de Pesquisa e Desenvolvimento (CNPq, INCTTox) and Coordenação de Aperfeiçoamento de Pessoal de Nível Superior (CAPES).

Competing interests The authors declare that they have no competing interests.

Open Access This article is distributed under the terms of the Creative Commons Attribution License which permits any use, distribution, and reproduction in any medium, provided the original author(s) and the source are credited.

\section{References}

1. King FW, Fong S, Griffin C, Shoemaker M, Staub R, Zhang YL, Cohen I, Shtivelman E (2009) Timosaponin AIII is preferentially cytotoxic to tumor cells through inhibition of mTOR and induction of ER stress. PLoS One 4(9):e7283. doi:10.1371/journal.pone.0007283

2. Hanahan D, Weinberg RA (2011) Hallmarks of cancer: the next generation. Cell 144(5):646-674. doi:10.1016/j.cell.2011.02.013

3. Marzetti E, Lawler JM, Hiona A, Manini T, Seo AY, Leeuwenburgh C (2008) Modulation of age-induced apoptotic signaling and cellular remodeling by exercise and calorie restriction in skeletal muscle. Free Radic Biol Med 44(2):160-168. doi:10.1016/ j.freeradbiomed.2007.05.028
4. Denecker G, Vercammen D, Steemans M, Vanden Berghe T, Brouckaert G, Van Loo G, Zhivotovsky B, Fiers W, Grooten J, Declercq W, Vandenabeele P (2001) Death receptor-induced apoptotic and necrotic cell death: differential role of caspases and mitochondria. Cell Death Differ 8(8):829-840. doi:10.1038/sj.cdd.4400883

5. Lavrik IN (2010) Systems biology of apoptosis signaling networks. Curr Opin Biotechnol 21(4):551-555. doi:10.1016/ j.copbio.2010.07.001

6. Tsutsui H, Kinugawa S, Matsushima S (2011) Oxidative stress and heart failure. Am J Physiol Heart Circ Physiol 301(6):H2181-2190. doi:10.1152/ajpheart.00554.2011

7. Haynes CM, Titus EA, Cooper AA (2004) Degradation of misfolded proteins prevents ER-derived oxidative stress and cell death. Mol Cell 15(5):767-776. doi:10.1016/j.molcel.2004.08.025

8. Sy LK, Yan SC, Lok CN, Man RY, Che CM (2008) Timosaponin A-III induces autophagy preceding mitochondria-mediated apoptosis in HeLa cancer cells. Cancer Res 68(24):1022910237. doi:10.1158/0008-5472.CAN-08-1983

9. Azad N, Iyer A, Vallyathan V, Wang L, Castranova V, Stehlik C, Rojanasakul Y (2010) Role of oxidative/nitrosative stress-mediated Bcl-2 regulation in apoptosis and malignant transformation. Ann N Y Acad Sci 1203:1-6. doi:10.1111/j.1749-6632.2010.05608.x

10. Singh SV, Srivastava SK, Choi S, Lew KL, Antosiewicz J, Xiao D, Zeng Y, Watkins SC, Johnson CS, Trump DL, Lee YJ, Xiao H, Herman-Antosiewicz A (2005) Sulforaphane-induced cell death in human prostate cancer cells is initiated by reactive oxygen species. J Biol Chem 280(20):19911-19924. doi:10.1074/jbc.M412443200

11. Hancock JT, Desikan R, Neill SJ (2001) Role of reactive oxygen species in cell signalling pathways. Biochem Soc Trans 29(Pt 2):345-350

12. Griscavage JM, Hobbs AJ, Ignarro LJ (1995) Negative modulation of nitric oxide synthase by nitric oxide and nitroso compounds. Adv Pharmacol 34:215-234

13. Hikita H, Takehara T, Shimizu S, Kodama T, Shigekawa M, Iwase K, Hosui A, Miyagi T, Tatsumi T, Ishida H, Li W, Kanto T, Hiramatsu N, Hayashi N (2010) The Bcl-xL inhibitor, ABT-737, efficiently induces apoptosis and suppresses growth of hepatoma cells in combination with sorafenib. Hepatology 52(4):1310-1321. doi: $10.1002 /$ hep. 23836

14. Shankar S, Srivastava RK (2007) Involvement of Bcl-2 family members, phosphatidylinositol 3'-kinase/AKT and mitochondrial p53 in curcumin (diferulolylmethane)-induced apoptosis in prostate cancer. Int J Oncol 30(4):905-918

15. Dlamini Z, Mbita Z, Zungu M (2004) Genealogy, expression, and molecular mechanisms in apoptosis. Pharmacol Ther 101(1):1-15

16. Scorrano L, Oakes SA, Opferman JT, Cheng EH, Sorcinelli MD, Pozzan T, Korsmeyer SJ (2003) BAX and BAK regulation of endoplasmic reticulum $\mathrm{Ca} 2+$ : a control point for apoptosis. Science 300(5616):135-139. doi:10.1126/science.1081208

17. Soriano ME, Scorrano L (2010) The interplay between BCL-2 family proteins and mitochondrial morphology in the regulation of apoptosis. Adv Exp Med Biol 687:97-114

18. Vogelstein B, Lane D, Levine AJ (2000) Surfing the p53 network. Nature 408(6810):307-310. doi:10.1038/35042675

19. Jin S, Levine AJ (2001) The p53 functional circuit. J Cell Sci 114 (Pt 23):4139-4140

20. Slee EA, O'Connor DJ, Lu X (2004) To die or not to die: how does p53 decide? Oncogene 23(16):2809-2818. doi:10.1038/sj.onc.1207516

21. Chipuk JE, Kuwana T, Bouchier-Hayes L, Droin NM, Newmeyer DD, Schuler M, Green DR (2004) Direct activation of Bax by p53 mediates mitochondrial membrane permeabilization and apoptosis. Science 303(5660):1010-1014. doi:10.1126/science.1092734

22. Mihara M, Erster S, Zaika A, Petrenko O, Chittenden T, Pancoska P, Moll UM (2003) p53 has a direct apoptogenic role at the mitochondria. Mol Cell 11(3):577-590

23. Bakhshi J, Weinstein L, Poksay KS, Nishinaga B, Bredesen DE, Rao RV (2008) Coupling endoplasmic reticulum stress to the cell 
death program in mouse melanoma cells: effect of curcumin. Apoptosis 13(7):904-914. doi:10.1007/s10495-008-0221-x

24. Drexler HC (2009) Synergistic apoptosis induction in leukemic cells by the phosphatase inhibitor salubrinal and proteasome inhibitors. PLoS One 4(1):e4161. doi:10.1371/journal.pone.0004161

25. Nawrocki ST, Carew JS, Pino MS, Highshaw RA, Dunner K Jr, Huang P, Abbruzzese JL, McConkey DJ (2005) Bortezomib sensitizes pancreatic cancer cells to endoplasmic reticulum stress-mediated apoptosis. Cancer Res 65(24):11658-11666. doi:10.1158/0008-5472.CAN-05-2370

26. Deniaud A, Sharaf el dein O, Maillier E, Poncet D, Kroemer G, Lemaire C, Brenner C (2008) Endoplasmic reticulum stress induces calcium-dependent permeability transition, mitochondrial outer membrane permeabilization and apoptosis. Oncogene 27 (3):285-299. doi:10.1038/sj.onc.1210638

27. Kostova Z, Wolf DH (2003) For whom the bell tolls: protein quality control of the endoplasmic reticulum and the ubiquitin-proteasome connection. EMBO J 22(10):2309-2317. doi:10.1093/emboj/cdg227

28. Tsai B, Ye Y, Rapoport TA (2002) Retro-translocation of proteins from the endoplasmic reticulum into the cytosol. Nat Rev 3 (4):246-255. doi:10.1038/nrm780

29. Nawrocki ST, Sweeney-Gotsch B, Takamori R, McConkey DJ (2004) The proteasome inhibitor bortezomib enhances the activity of docetaxel in orthotopic human pancreatic tumor xenografts. Mol Cancer Ther 3(1):59-70

30. Fribley A, Zeng Q, Wang CY (2004) Proteasome inhibitor PS-341 induces apoptosis through induction of endoplasmic reticulum stress-reactive oxygen species in head and neck squamous cell carcinoma cells. Mol Cell Biol 24(22):9695-9704. doi:10.1128/ MCB.24.22.9695-9704.2004

31. Schroder M, Kaufman RJ (2005) The mammalian unfolded protein response. Annu Rev Biochem 74:739-789. doi:10.1146/ annurev.biochem.73.011303.074134

32. Rutkowski DT, Kaufman RJ (2004) A trip to the ER: coping with stress. Trends Cell Biol 14(1):20-28

33. Orrenius S, Zhivotovsky B, Nicotera P (2003) Regulation of cell death: the calcium-apoptosis link. Nat Rev 4(7):552-565. doi:10.1038/nrm1150

34. Chudzinski-Tavassi AM, De-Sa-Junior PL, Simons SM, Maria DA, de Souza VJ, Batista IF, Faria F, Duraes E, Reis EM, Demasi M (2010) A new tick Kunitz type inhibitor, Amblyomin-X, induces tumor cell death by modulating genes related to the cell cycle and targeting the ubiquitin-proteasome system. Toxicon 56 (7):1145-1154. doi:10.1016/j.toxicon.2010.04.019

35. Batista IF, Ramos OH, Ventura JS, Junqueira-de-Azevedo IL, Ho PL, Chudzinski-Tavassi AM (2010) A new Factor Xa inhibitor from Amblyomma cajennense with a unique domain composition. Arch Biochem Biophys 493(2):151-156. doi:10.1016/j.abb.2009.10.009

36. Akagi EM, Junior PL, Simons SM, Bellini MH, Barreto SA, Chudzinski-Tavassi AM (2012) Pro-apoptotic effects of Amblyomin-X in murine renal cell carcinoma "in vitro". Biomed Pharmacother 66(1):64-69. doi:10.1016/j.biopha.2011.11.015

37. Bellini MH, Coutinho EL, Courrol LC, de Oliveira R, Silva F, Vieira Junior ND, Schor N (2008) Correlation between autofluorescence intensity and tumor area in mice bearing renal cell carcinoma. J Fluoresc 18(6):1163-1168. doi:10.1007/s10895-008-0368-4

38. Rocha FG, Calvo FB, Chaves KC, Peron JP, Marques RF, de Borba TR, Braga MS, Pereira CB, Vicente EJ, Chammas R, Schor N, Bellini MH (2011) Endostatin- and interleukin-2expressing retroviral bicistronic vector for gene therapy of metastatic renal cell carcinoma. J Gene Med 13(3):148-157. doi:10.1002/jgm.1547

39. Murphy GP, Hrushesky WJ (1973) A murine renal cell carcinoma. J Natl Cancer Inst 50(4):1013-1025

40. Lameu C, Hayashi MA, Guerreiro JR, Oliveira EF, Lebrun I, Pontieri V, Morais KL, Camargo AC, Ulrich H (2010) The central nervous system as target for antihypertensive actions of a prolinerich peptide from Bothrops jararaca venom. Cytometry A 77 (3):220-230. doi:10.1002/cyto.a.20860

41. Livak KJ, Schmittgen TD (2001) Analysis of relative gene expression data using real-time quantitative PCR and the 2(-Delta Delta C(T)) Method. Methods 25(4):402-408. doi:10.1006/ meth.2001.1262

42. Pick E, Mizel D (1981) Rapid microassays for the measurement of superoxide and hydrogen peroxide production by macrophages in culture using an automatic enzyme immunoassay reader. J Immunol Methods 46(2):211-226

43. Kabore AF, Johnston JB, Gibson SB (2004) Changes in the apoptotic and survival signaling in cancer cells and their potential therapeutic implications. Curr Cancer Drug Targets 4(2):147-163

44. Maddika S, Ande SR, Panigrahi S, Paranjothy T, Weglarczyk K, Zuse A, Eshraghi M, Manda KD, Wiechec E, Los M (2007) Cell survival, cell death and cell cycle pathways are interconnected: implications for cancer therapy. Drug Resist Updat 10(1-2):13-29. doi:10.1016/j.drup.2007.01.003

45. Kim R, Emi M, Matsuura K, Tanabe K (2007) Antisense and nonantisense effects of antisense Bcl-2 on multiple roles of Bcl-2 as a chemosensitizer in cancer therapy. Cancer Gene Ther 14(1):1-11. doi:10.1038/sj.cgt.7700986

46. Oltersdorf T, Elmore SW, Shoemaker AR, Armstrong RC, Augeri DJ, Belli BA, Bruncko M, Deckwerth TL, Dinges J, Hajduk PJ, Joseph MK, Kitada S, Korsmeyer SJ, Kunzer AR, Letai A, Li C, Mitten MJ, Nettesheim DG, Ng S, Nimmer PM, O'Connor JM, Oleksijew A, Petros AM, Reed JC, Shen W, Tahir SK, Thompson CB, Tomaselli KJ, Wang B, Wendt MD, Zhang H, Fesik SW, Rosenberg SH (2005) An inhibitor of Bcl-2 family proteins induces regression of solid tumours. Nature 435(7042):677-681. doi:10.1038/nature03579

47. Ralph SJ, Low P, Dong L, Lawen A, Neuzil J (2006) Mitocans: mitochondrial targeted anti-cancer drugs as improved therapies and related patent documents. Recent Pat Anticancer Drug Discov 1 (3):327-346

48. Biasutto L, Dong LF, Zoratti M, Neuzil J (2010) Mitochondrially targeted anti-cancer agents. Mitochondrion 10(6):670-681. doi:10.1016/j.mito.2010.06.004

49. Mimnaugh EG, Xu W, Vos M, Yuan X, Isaacs JS, Bisht KS, Gius D, Neckers L (2004) Simultaneous inhibition of hsp 90 and the proteasome promotes protein ubiquitination, causes endoplasmic reticulum-derived cytosolic vacuolization, and enhances antitumor activity. Mol Cancer Ther 3(5):551566

50. Ellgaard L, Helenius A (2003) Quality control in the endoplasmic reticulum. Nat Rev 4(3):181-191. doi:10.1038/nrm1052

51. Nakagawa T, Zhu H, Morishima N, Li E, Xu J, Yankner BA, Yuan J (2000) Caspase-12 mediates endoplasmic-reticulum-specific apoptosis and cytotoxicity by amyloid-beta. Nature 403(6765):98103. doi: $10.1038 / 47513$

52. Faitova J, Krekac D, Hrstka R, Vojtesek B (2006) Endoplasmic reticulum stress and apoptosis. Cell Mol Biol Lett 11(4):488-505. doi:10.2478/s11658-006-0040-4

53. Rahmani M, Davis EM, Crabtree TR, Habibi JR, Nguyen TK, Dent P, Grant S (2007) The kinase inhibitor sorafenib induces cell death through a process involving induction of endoplasmic reticulum stress. Mol Cell Biol 27(15):5499-5513. doi:10.1128/ MCB.01080-06

54. Santos CX, Tanaka LY, Wosniak J, Laurindo FR (2009) Mechanisms and implications of reactive oxygen species generation during the unfolded protein response: roles of endoplasmic reticulum oxidoreductases, mitochondrial electron transport, and NADPH oxidase. Antioxid Redox Signal 11(10):2409-2427. doi:10.1089/ARS.2009.2625 
55. Zong WX, Li C, Hatzivassiliou G, Lindsten T, Yu QC, Yuan J, Thompson CB (2003) Bax and Bak can localize to the endoplasmic reticulum to initiate apoptosis. J Cell Biol 162(1):59-69. doi: $10.1083 /$ jcb. 200302084

56. Wei MC, Lindsten T, Mootha VK, Weiler S, Gross A, Ashiya M, Thompson CB, Korsmeyer SJ (2000) tBID, a membrane-targeted death ligand, oligomerizes BAK to release cytochrome c. Genes Dev 14(16):2060-2071

57. Germain M, Shore GC (2003) Cellular distribution of Bcl-2 family proteins. Science's STKE : signal transduction knowledge environment 2003 (173):pe10. doi: 10.1126/stke. 2003.173.pe 10 